\title{
A Procedural Approach to the Contract Clause
}

The modern history of the contract clause ${ }^{1}$ has been a history of balancing the rights of contractors against the demands of the state. ${ }^{2}$ This Note argues that a balancing approach to the contract clause is undesirable as a matter of policy and of constitutional law. By increasing judicial discretion, balancing creates uncertainty in the law and undermines the integrity of the legal system. Moreover, a balancing approach to the contract clause is inconsistent with the Framers' intent and with the text of the Constitution.

The Note proposes a procedural interpretation of the contract clause. Under this proposal, judges would interpret the contract clause to allow prospective changes in contract law by the legislature, but to prohibit all retroactive impairments without payment of just compensation. The Note's proposal would increase the chance that only impairments in the

1. The contract clause provides: "No State shall . . . pass any . . . Law impairing the Obligation of Contracts . . . ." U.S. ConST. art. I, $\S 10$, cl. 6.

2. The landmark balancing case is Home Bldg. \& Loan Ass'n v. Blaisdell, 290 U.S. 398 (1934). There, the Supreme Court upheld an emergency moratorium on mortgage debts. The Court listed five factors that legitimated the impairment despite the claim of unconstitutionality: (1) the existence of a declared emergency; (2) the protection of a basic societal interest rather than particular individuals; (3) the tailoring of the relief to the need it was designed to meet; (4) the presence of reasonable conditions, such as the continuation of the mortgagors' interest obligations and the fact that most mortgagees were corporations, whose chief concern was investment security; and (5) the limitation of the legislation to the duration of the emergency. Id. at 444-48. Six years later, the Supreme Court eliminated two of these factors and added another. See Veix v. Sixth Ward Bldg. \& Loan Ass'n, 310 U.S. 32, 38 (1940) (relief need not be declared and relief measure need not be temporary; contract was in area already subject to regulation); see also United States Trust Co. v. New Jersey, 431 U.S. 1, 26, 31 (1977) (adding as factors stricter scrutiny for public contracts and whether effect of contract was foreseeable when formed).

Blaisdell and Veix were followed by a number of other balancing cases. See City of El Paso v. Simmons, 379 U.S. 497, 508-09 (1965) (impairment of land purchaser's bargained-for right to reinstatement held reasonable); East N.Y. Sav. Bank v. Hahn, 326 U.S. 230 (1945) (mortgage moratorium constitutional); Faitoute Iron \& Steel Co. v. City of Asbury Park, 316 U.S. 502 (1942) (reduction of municipal bondholders' rights constitutional).

Recent Supreme Court cases continue to reflect the Court's preference for balancing tests in interpreting the contract clause. See Exxon Corp. v. Eagerton, 103 S. Ct. 2296, 2305 (1983) (upholding Alabama law preventing oil producers from exercising their bargained right to pass on tax increases as part of "inherent police power of the state "to safeguard the vital interests of its people" ") (citations omitted); Energy Reserves Group v. Kansas Power \& Light Co., 103 S. Ct. 697, 708 (1983) (upholding Kansas law limiting contractual right of natural gas producers to pass on price increases as insignificant impairment, furthering "significant and legitimate state interests" in protecting consumers from price rise caused by deregulation and in coordinating markets); Allied Structural Steel Co. v. Spannaus, 438 U.S. 234, 240-41 (1978) (clause "not . . . the Draconian provision that its words might seem to imply" and it is "a commonplace that the contract clause does not . . obliterate the police power"); United States Trust Co. v. New Jersey, 431 U.S. 1, 25 (1977) ("The Contract Clause is not an absolute bar to subsequent modifications of a State's own financial obligations. As with laws impairing the obligations of private contracts, an impairment [of a public contract] may be constitutional if it is reasonable and necessary to serve an important public purpose.") (footnote omitted). 
public interest will be made. The Note concludes by considering the implications of the proposal for corporate law.

\section{The Balancing Approach to the Contract Glause}

\section{A. Contract Clause Jurisprudence Relies on Balancing Tests}

Despite the absolute language of the contract clause, courts have not recently interpreted the clause to prohibit all impairment of contracts. ${ }^{3}$ Instead, they have balanced contractors' private rights with the public interest in a manner reminiscent of Lochner v. New York. ${ }^{*}$ This use of balancing is central to the modern understanding of the contract clause. ${ }^{5}$ Their unanimous support for balancing is all the more striking in that there is nothing in the text or history of the contract clause that suggests that balancing is appropriate. ${ }^{\circ}$

\section{B. Policy Disadvantages of Contract Clause Balancing}

The balancing approach to the contract clause allows judges excessive discretion. ${ }^{7}$ This broad discretion is undesirable for policy reasons because

3. During the early nineteenth century, courts interpreted the contract clause as absolute. See United States Trust Co. v. New Jersey, 431 U.S. 1, 20 n.17 (1977) ("During the early years . . . the contract clause was regarded as an absolute bar to any impairment."); Trustees of Dartmouth College v. Woodward, 17 U.S. 518 (1819); Fletcher v. Peck, 10 U.S. 87, 135-38 (1810) ("When . . . a law is in its nature a contract, when absolute rights have vested under that contract, a repeal of that law cannot divest those rights .....") (emphasis added). During this period, the contract clause was the basis of more Supreme Court decisions than any other constitutional clause. See B. SchwARTZ, A Commentary on the Constitution of the Untede States: Part II, The Rights of ProperTy 267 (1965); B. Wright, The Contract Clause of the Constitution xiii (1938). The clause's importance was captured by the British observer, Sir Henry Maine, who said:

I have seen the [the contract clause] criticised as if it were a mere politico-economic flourish;

but in point of fact there is no more important provision in the whole Constitution . . . . [I]t

is this prohibition which has in reality secured full play to the economical forces by which the

achievement of cultivating the soil of the North American Continent has been performed; it is

the bulwark of American Individualism against democratic impatience and Socialistic fantasy.

H. Maine, Popular Government 247-48 (1885).

4. 198 U.S. 45 (1905).

5. For a time, it seemed that the Supreme Court Justices could agree on little besides the appropriateness of balancing. See Allied Structural Steel Co. v. Spannaus, 438 U.S. 234 (1978) (Both majority and dissent support balancing, but dissent charges majority with "fundamentally misconceiv[ing]" contract clause); United States Trust Co. v. New Jersey, 431 U.S. 1, 45 (1977) (same). But see Exxon Corp. v. Eagerton, 103 S. Ct. 2296 (1983) (unanimous Court upholding law nullifying contractual obligation); Energy Reserves Group v. Kansas Power \& Light Co., 103 S. Ct. 697 (1983) (majority and concurrence in substantial agreement).

6. See infra pp. 922-25.

7. The test announced in United States Trust Co. v. New Jersey, 431 U.S. 1, 25 (1977), is illustrative. There, the Court held that "an impairment may be constitutional if it is reasonable and necessary to serve an important public purpose." Terms like "reasonable" or "important public purpose" are so vague that they inevitably depend on the view of individual justices. See infra note 10 (in Allied Structural Steel and United States Trust Co., conservative justices considered impairment unreasonable and public purpose minor, but liberal justices deemed impairment reasonable and public purpose significant); see also infra note 53 (justices employ philosophical rather than technical concepts). Discretion is not even limited by the requirement that an impairment be "necessary." Neces- 
it distorts the law. It undermines the process of overturning precedent. Moreover, excessive discretion generates uncertainty, undermines the goals of a written constitution, and impairs the rule of law.

Precedents should be overturned openly to ensure that the legal community can scrutinize changes in the law. The contract clause balancing test, however, permits judges to change the law without having to overrule past decisions explicitly: Balancing allows judges to weigh competing values on an ad hoc basis, which permits them to change the weight they give to different values over time. In theory, of course, judges should decide balancing issues consistently: Two similar cases requiring balancing should be decided in the same way. But since the contract clause balancing test does not force judges to state their past decisions in the form of a rule, ${ }^{8}$ they are often able to evade these decisions. Judges have thus modified sub silentio the law governing contract impairment. ${ }^{\circ}$

sity has no determinate meaning in this context because the state can always use its powers of eminent domain or taxation. See United States Trust Co. v. New Jersey, 431 U.S. at 19 \& n.16, 59 (Brennan, J., dissenting) ("in virtually every decided Contract Clause case, the government could have exercised ... 'lesser alternative' of resorting to its power of taxation as a substitute for modifying ... contracts").

The Supreme Court will sometimes supplement these vague terms with more specific criteria. See Veix v. Sixth Ward Bldg. \& Loan Ass'n, 310 U.S. 32, 38 (1940) (contract in area already subject to regulation); Home Bldg. \& Loan Ass'n v. Blaisdell, 290 U.S. 398, 444 (1934) (existence of declared emergency). However, since the Court has changed these criteria so often, see supra note 2, their contribution is marginal.

8. Even though this Note employs exacting standards in assessing judicial interpretation, it does not assume an unrealistic or mechanistic view of legal interpretation. The feasibility of rule-based interpretation might be illustrated by imagining the following spectrum of legal forms. Laws at one end of the spectrum are clear enough to be applied mechanically. Laws in the center of the spectrum are still rules, but require interpretation: The words of the rules must be defined more clearly and applications must be made apparent. At the far end of the spectrum lies balancing. Here, the law is so vague as to be no more than a list of values to be weighed by the judges.

This Note assumes the law in the center of the spectrum, not at the far (mechanistic) end. It thus recognizes that meaning must be given to the words of the contract clause. The definition, for example, of "obligation," "impairment," or even "law" is of crucial importance. Thus, even an absolutist approach leaves room for some judicial interpretation. However, since words can be interpreted in terms of rules-e.g., an obligation always refers to an existing contract-judicial interpretation need not involve ad hoc balancing. See also Henkin, Infallibility Under Law: Constitutional Balancing, 78 Golum. L. Rev. 1022, 1027 (1978) (distinguishing "interpretive balancing," which is consistent with rule-based law, from ad hoc balancing, which is not).

9. The Court's enthusiasm for the contract clause has fluctuated significantly, but the Justices still write as if their holdings under the clause are consistent. See Allied Structural Steel Co. v. Spannaus, 438 U.S. 234, 242-43 (1978) (deriving principles of contract clause jurisprudence from Blaisdell and El Paso); United States Trust Co. v. New Jersey, 431 U.S. 1, 15, 16 (1977) (same). This position is extraordinary since the various holdings under the clause cannot be reconciled: Many of the contract clause cases reflect the eras in which they were written. See infra note 12 . Handed down during the Great Depression, Blaisdell was a five-to-four decision that reluctantly upheld a statute permitting mortgagors to remain in their houses a few extra months if they compensated the mortgagees with reasonable rental value. The statute was justified as a temporary measure pursuant to a declared emergency, and it is not clear that any actual damages were suffered by the mortgagees. El Paso, on the other hand, was an eight-to-one decision made in the prosperous mid-1960's. There, the Court upheld a Texas statute depriving land purchasers, without compensation, of their bargained-for right to reinstatement. The rationales for upholding the impairment-clarification of land titles, elimination of litigation, and effective use and utilization of property-seem relatively trivial compared to the 
The contract clause balancing test also interferes with the ordering function of the law. Individual judges exercise their broad discretion under the contract clause balancing test differently. ${ }^{10}$ Because no one can predict who will judge any particular case, the balancing test creates unnecessary uncertainty and denies notice, making it difficult for people to plan and order their lives. ${ }^{11}$

Paradoxically, the judicial discretion allowed by the contract clause balancing test may also restrain judicial independence, for it eliminates one of the judges' most effective shields against prevailing opinion-legal certainty. Because judges cannot plausibly argue that their unpopular con-

losses suffered by the contractors. The true motivation for the impairment was suggested by Justice Black: "At most the Court's reasons boil down to the fact that Texas' contracts . . . turned out . . . to be costly . . . The State decided it had made a bad deal and wanted out." City of El Paso v. Simmons, 379 U.S. 497, 352 (1965) (Black, J., dissenting). Blaisdell and El Paso reveal very different judicial attitudes toward the contract clause. In Blaisdell, the Court considered upholding an impairment a serious course of action to be pursued only in support of very important social values, whereas in El Paso the Court was almost frivolous in its consideration of the importance of judicial protection of contract rights. The Court gave no indication that the law had changed.

The Court changed its interpretation of the contract clause again in 1977. In United States Trust Co. v. New Jersey, 431 U.S. 1 (1977), it indicated that impairments of a state's own contracts would face more stringent examination since a state's self-interest was at stake. Id. at 26; see also Exxon Corp. v. Eagerton, 103 S. Ct. 2296, 2306 (1983) (noting stricter scrutiny appropriate for impairments of public contracts); Energy Reserves Group v. Kansas Power \& Light Co., 103 S. Ct. 697, 705 n.14 (1983) (same). This willingness to look beyond the government's stated purpose differs radically from the Court's deferential attitude in El Paso.

10. Two recent contract clause cases, United States Trust Co. v. New Jersey, 431 U.S. 1 (1977), and Allied Structural Steel Co. v. Spannaus, 438 U.S. 234 (1978), illustrate the point. The conservative justices seemed to favor contract rights while liberal justices did not. In Spannaus, the majority thought "the effect of ... . [the impairment] was severe, . . . in an area where the element of reliance was vital." Id. at 246 (Stewart, J.) (joined by Burger, C.J., Powell, Rehnquist \& Stevens, JJ.). The dissent, in contrast, claimed that "the Act does not impose 'sudden and unanticipated' burdens . . . [and] will impose only minor economic burdens on employers whose pension plans have been adequately funded." Id. at 253-54 (Brennan, J., dissenting) (joined by White \& Marshall, JJ.). The Justices also disagreed as to the importance of the purposes achieved by the Act. The dissenters wrote, "The Act . . . was designed to remedy a serious social problem," id. at 252, but the majority stated "not only did the Act have an extremely narrow aim, but also its effective life was extremely short," id. at 248 n.21.

In United States Trust Co., the majority described the statute as working a "drastic impairment," id. at 31 (Blackmun, J.) (joined by Burger, C.J., Rehnquist \& Stevens, JJ.). The dissenters considered the impairment to cause only "the most minimal damage on the part of the Authority's bondholders." Id. at 41 (Brennan, J., dissenting) (joined by White \& Marshall, JJ.). Referring to the purpose of the statute, the dissenters wrote that it responded to "serious and growing environmental, energy, and transportation problems," id. at 38, while the majority stated that the "changes [in these problems] . . . were of degree and not of kind," id. at 32.

11. See L. Fulier, The MoraltTy of Law 33-62 (1971); F. Hayek, The Constitution of LIBERTY 133-61 (1960). Since contracts are one of the main instruments by which individuals can create order in society, uncertainty as to the law of contracts is particularly harmful. By increasing the cost of contracting, uncertainty discourages mutually beneficial exchanges and thus harms rich and poor alike. Uncertainty does not even promote distributional goals. If the courts attempted to use their discretion to aid the poor, such attempts would soon prove to be counterproductive, since contractors would add a risk premium equal to their expected loss from the impairment to any contracts they made with poor people. See Trebilcock, The Doctrine of Inequality of Bargaining Power, in THE Economics of Contract Law 91-92 (A. Kronman \& R. Posner eds. 1979). But see Kennedy, Forn and Substance in Private Law Adjudication, 89 HARv. L. REv. 1685, 1777-78 (1976). 
tract clause decisions are compelled by the rigors of a clear legal rule, judges will have greater difficulty in standing firm against popular trends that threaten constitutional values. ${ }^{12}$ It is the purpose of a written constitution-and in America, of the judiciary that interprets the Constitution-to stand as an impediment to such trends. ${ }^{13}$ It is the nature of balancing tests to encourage them.

Finally, the contract clause balancing test undermines the legitimacy of the judicial process, which asks judges to make retrospective decisions about particular known individuals. In contrast, legislators render prospective decisions for large classes of people. ${ }^{14}$ The judicial enterprise thus allows judges more opportunity to act out of bias than legislators; accordingly, many safeguards exist to limit the discretion of individual judges. ${ }^{15}$ No such safeguard is more important than the requirement that judges decide cases in accordance with rules. This requirement helps to ensure that standards of justice are applied universally and consistently, and limits the ability of judges to act out of bias since judges know that their rulings will apply in cases not yet in court to parties they cannot foresee. By enabling judges to circumvent the requirement of rules with ad hoc decisions, the contract clause balancing test undermines this important safeguard. ${ }^{16}$

12. Cf. Wechsler, Toward Neutral Principles of Constitutional Law, 73 HARv. L. REv. 1, 10 (1959) (lack of discretionary jurisdiction in Marshall Court protected constitutional values against popular sentiments). Notably the landmark balancing case, Blaisdell, was decided during the Great Depression, when belief in private ordering was at its lowest. Similarly, the El Paso decision of the mid-1960's reflects that era's faith in the fairness and efficacy of government. More recent cases, which place greater value on contract rights, see Allied Structural Steel, 438 U.S. 234 (1978); United States Trust Co. 431 U.S. 1 (1977), coincide with a general turn toward conservative values.

13. See Black, The Bill of Rights, 35 N.Y.U. L. REv. 865, 870 (1965) (arguing that Bill of Rights be interpreted in absolute terms). Both interpretivists and noninterpretivists accept the importance of an independent judiciary. See id. at 869-70 (independent judiciary limits arbitrary government); Fiss, The Supreme Court, 1978 Term-Foreword: The Forms of Justice, 93 HaRv. L. REv. 1, 11-17 (1979) (suggesting that judges are qualified to interpret conflicting values in Constitution since they are independent of politics and democratic decisionmaking). But see Wellington, Common Law Rules and Constitutional Double Standards: Some Notes on Adjudication, 83 YALE L.J. 221, 265-80 (1973) (advocating constitutional interpretation based upon popular moral standards).

14. L. Tribe, american Constitutional Law $\$$ 10-1 to 10-18, at 474-519 (1978); Comment, The Bounds of Legislative Specification: A Suggested Approach to the Bill of Attainder Clause, 72 YALE L.J. 330, 347 (1962). Unfortunately, legislative decisionmaking is not prospective and general enough to ensure decisionmaking in the public interest. John Hart Ely's theory of judicial review is based upon the failure of legislators to make fully general decisions. See J. ELY, Democracy and DisTrust 80-102 (1980). This Note also attempts to improve the generality and prospectivity of legislative decisionmaking. See infra pp. 925-29.

15. The rights to a jury's determination of facts and to disqualify biased judges are both mechanisms that limit a judge's ability to act improperly.

16. The separation of powers is also undermined when judges decide cases without reference to clear rules. The doctrine of separation of powers presumes that laws exist which the judiciary cannot easily alter. See F. HAYEK, supra note 11, at 210-12. Balancing under the contract clause provides judges with such unlimited discretion that they can in effect exercise both the judicial and legislative power at once. 


\section{Constitutional Arguments Against Balancing}

The contract clause balancing test suffers from constitutional as well as policy defects. Those defects are manifest whether one looks to the constitutional text or the Framers' intent. To treat the contract clause as analogous to the doctrine of "substantive due process" is also a mistake.

\section{Constitutional Text and the Intent of the Framers}

Since the text of the contract clause relies on absolute language, it suggests that balancing should not be employed, and early courts viewed the clause as an absolute prohibition on contract impairment. ${ }^{17}$ Some constitutional clauses, in contrast, do suggest the appropriateness of balancing: The Fourth Amendment prohibits "unreasonable searches and seizures,"18 and the Eighth Amendment guarantees that "excessive bail shall not be required, nor excessive fines imposed."19 Had the Framers intended balancing under the contract clause, they could have prohibited only unreasonable impairments. ${ }^{20}$ Since they failed to do this, however, the Court's use of balancing would appear to result from an incorrect interpretation.

Historical evidence also indicates that the Framers did not intend to create a balancing test under the contract clause. ${ }^{21}$ Madison considered impairments of contract to be a great evil: "[L]aws impairing the obliga-

17. See Hale, The Supreme Court and the Contract Clause (pt. 3), 57 Harv. L. Rev. 852, 872-74 (1944); supra note 3.

18. U.S. ConsT. amend. IV (emphasis added).

19. U.S. CoNST. amend. VIII (emphasis added).

20. This argument parallels that of Justice Black concerning the First Amendment. See Black, supra note 13 (advocating absolutist approach to constitutional interpretation); see also City of El Paso v. Simmons, 379 U.S. 497, 517 (1965) (Black, J., dissenting) (suggesting that contract clause is absolute bar to impairment of contracts). Even though the First Amendment employs absolute language, absolute interpretations have been criticized as unworkable. See J. ELY, supra note 14, at 109-10; Mendelson, The First Amendment and the Judicial Process: A Reply to Mr. Frantz, 17 VAND. L. REv. 479 (1964). But see J. Ely, supra note 14, at 110-16 (proposing interpretation of First Amendment that circumvents difficulties of an absolute approach, but also avoids the dangers of ad hoc balancing). According to Professor Tribe, the Supreme Court employs ad hoc balancing only when "a government regulation is aimed at the noncommunicative impact of an act." L. TRIBE, supra note $14, \S 12-2$, at 582 . The absolute approach advocated in this Note is here applied only to the contract clause. Even if absolute approaches should prove unworkable in other areas of constitutional jurisprudence, it is significant that balancing is unnecessary under the contract clause. Two features of the contract clause particularly suit it to an absolute interpretation. First, the clause protects only existing contracts. The states can therefore regulate contract law prospectively. See infra pp. 925-28. The First Amendment, however, prevents the government from abridging free speech with either prospective or retroactive laws. Second, because contracts are a form of property, the states can impair if they pay just compensation. See infra pp. 928-29; pp. 933. Government restriction of speech, however, is more difficult to cure with damage payments.

21. W. Hunting, The Obligation of Contracts Clause of The United States ConstiTUTION 119 (1919) (suggesting that "Madison admitted that inconveniences might arise from such a prohibition, but thought these overbalanced by the utility of it"); B. ScHWARTz, supra note 3, at 266-67 (1965). 
tion of contracts . . . are contrary to the first principles of the social compact and to every principle of sound legislation."22 Moreover, discussion of the clause at the time of its ratification ${ }^{23}$ assumed that it would operate absolutely. ${ }^{24}$

\section{The False Analogy to Substantive Due Process}

Another constitutional problem with the contract clause balancing test is that it has relied on a false analogy to substantive due process. During the Lochner era, the Court viewed both the contract clause and the due process clause as involving the balancing of economic rights with the public interest. ${ }^{25}$ Commentators accepted this view and considered the contract clause to duplicate substantive due process. ${ }^{26}$

The discrediting of economic due process ${ }^{27}$ therefore greatly influenced the Court's reading of the contract clause. If judges could no longer decide cases involving economic rights asserted under the due process clause, how could they decide such cases under the contract clause? In this fashion, the false analogy to substantive due process reduced scrutiny under the contract clause to little more than rational-relation review. ${ }^{28}$

22. The Federalist No. 44, at 282 (J. Madison) (C. Rossiter ed. 1961).

23. See id. at 282-83. Luther Martin, a delegate to the Federal convention, opposed the clause because he believed its absolute effect would be too inflexible. Martin believed

that there might be times of such great public calamities and distress . . . as should render it the duty of a government, for the preservation of even the most valuable part of its citizens, in some measure to interfere in their favour, by passing laws totally or partially stopping the courts of justice, or authorizing the debtor to pay by installments .... I therefore voted against depriving the States of this power, a power which I am decided they ought to possess, but which, I admit, ought only to be exercised on very important and urgent occasions.

B. WRIGHT, supra note 3, at 13 (emphasis omitted). The last sentence suggests that Martin might have favored a balancing test. Modern courts have ignored the fact that Madison's views, not Martin's, prevailed at the Constitutional Convention.

24. An absolute reading of the clause does not cripple the powers of government for which the Framers provided. Although the clause is not limited by a balancing requirement, it is restricted in other ways. The clause applies only to action by the states and not by the federal government, and to retroactive but not prospective impairment. The Framers left room for governmental action, but, as always, they imposed restrictions upon it.

25. See Atlantic Coast Line v. Goldsboro, 232 U.S. 548, 558 (1914) ("neither the 'contract' clause nor the 'due process' clause has the effect of overriding the power of the State to establish all regulations that are reasonably necessary to secure the health, safety, good order, comfort, or general welfare of the community") (emphasis added); Manigault v. Springs, 199 U.S. 473, 480 (1905) (contract clause does not restrain police power).

26. See B. ScHWARTZ, supra note 3, at 306 (suggesting that decline of substantive due process has left contract clause as "fifth wheel to the Constitutional Law coach"); Hale, supra note 17, at 890-91 ("But the results might be the same if the contract clause were dropped out of the Constitution, and the challenged statutes all judged as reasonable or unreasonable deprivations of property.").

27. See Olsen v. Nebraska, 313 U.S. 236, 246 (1941); West Coast Hotel v. Parrish, 300 U.S. 379 (1937).

28. See United States Trust Co. v. New Jersey, 431 U.S. 1, 61 (1977) (Brennan, J., dissenting) (in "recent times, however, this Court wisely has come to embrace a coherent, unified interpretation of all such constitutional provisions [protecting property and contract rights], and has granted wide latitude to 'a valid exercise of [the States'] police powers,'... . even if it results in severe violations of 
The Court's analogy between the contract clause and substantive due process, however, is incorrect. The contract clause provides explicit textual protection of contract rights; the due process clause does not. Thus, the usual criticism that substantive due process involves judicial usurpation of legislative power ${ }^{2 \theta}$ does not apply to the contract clause. ${ }^{30}$ The discrediting of substantive due process should not, therefore, have limited rights under the contract clause. ${ }^{31}$

\section{The Procedural Approach to the Contract Glause}

The contract clause balancing test fails both on policy grounds and as a matter of constitutional law. This Note's proposal would eliminate the problems of the current balancing test. The Note interprets the contract clause to protect against all retroactive, uncompensated impairments. New laws that impair existing contracts are thus unconstitutional, but victims of contract impairments cannot enjoin enforcement of the impairment if a state chooses to pay damages. States retain the flexibility to impair retroactively, so long as they pay just compensation.

The Note also interprets the contract clause to permit the states to regulate contract law prospectively. ${ }^{32}$ The states should be able to make certain types of contracts illegal and impose limits on others. The clause does not, however, incorporate freedom of contract into the Constitution. The maximum hours statute at issue in Lochner v. New York, ${ }^{\text {s3 }}$ for example, would be constitutional to the extent that it applied to future contracts.

property right") (citations omitted; emphasis added); Day-Brite Lighting, Inc. v. Missouri, 342 U.S. 421, 423-25 (1952) (treating contract clause as duplicating due process clause); see also Energy Reserves Group v. Kansas Power \& Light Co., 103 S. Ct. 697, 705-06 (1983) (when private contracts are involved, "once a legitimate public purpose has been identified . . . as is customary in reviewing economic and social regulation ... courts properly defer to legislative judgment as to the necessity and reasonableness of a particular measure") (citations omitted).

29. See J. Ely, supra note 14, at 4-5; Bork, Neutral Principles and Some First Amendment Probleins, 47 IND. L.J. 1 (1971).

30. Disagreements over the due process analogy would seem to explain Justice Black's dissent in El Paso, 379 U.S. 497, 517 (1965). Given the majority's deference to the state legislature, id. at 512-14, it must have viewed the case as one fitting the model of economic due process. Justice Black, in contrast, read the contract clause as a separate provision in the Constitution.

31. Although this Note interprets the Constitution to protect certain economic rights, it avoids the pitfalls of "Lochnerizing" or of substantive due process. The interpretation presented below is based on values of process, is firmly rooted in the constitutional text, and does not involve judicial balancing. See infra pp. 934-35.

32. The Supreme Court has always interpreted the contract clause to allow prospective changes in contract law. See B. ScHWARTZ, supra note 3, at 273. In Ogden v. Saunders, 25 U.S. 213 (1827), the Court held that the contract clause applied only to retroactive impairments. Chief Justice Marshall, in dissent, argued that the Court's holding would undermine the clause since the states could now prospectively pass a law reserving the right to control all contracts. Id. at 355. This Note's procedural approach, however, forbids the states from reserving such impairment power. See supra p. 934-35.

33. 198 U.S. 45 (1905). 


\section{A. Policy Arguments for the Procedural Approach}

Legislators sometimes harm minority interests even when such harm is unnecessary for the general welfare. Requiring legislators to pass only prospective and general laws reduces the frequency of such unnecessary harm. ${ }^{\text {s4 }}$ The Framers implicitly recognized this by including several provisions in the Constitution that impose requirements of prospectivity and generality in legislation..$^{35}$ The contract clause should be interpreted as one such provision. ${ }^{36}$ The procedural approach ${ }^{37}$ to the contract clause, with its requirements of generality and prospectivity, is therefore desirable policy: It increases the chances that only impairments in the public interest will be made.

\section{Improved Legislative Decisionmaking}

The power to impair can be used for good or ill: A legislature might impair a contract to promote the general welfare or merely to benefit the politically powerful. The policy problem posed by the contract clause, therefore, is how to permit legitimate impairments while prohibiting illegitimate ones. This problem is addressed through a variety of mechanisms.

The procedural approach permits prospective changes in contract law because majorities ${ }^{98}$ are better able to abuse minorities with retroactive

34. F. HAyek, LAw, Legislation AND Liberty 3-21 (1979); F. HAYeK, supra note 11, at 205-20.

35. See J. ELY, supra note 14, at 88-100; infra pp. 932-33.

36. Curiously, John Hart Ely, the leading exponent of procedural interpretations of the Constitution, argues that the contract clause is substantive rather than procedural. Ely argues that the best explanation for the clause is that "the framers and ratifiers meant to single out for special protection from the . . . state political processes a substantive value." J. ELY, supra note 14, at 91-92 (emphasis omitted). If the clause is interpreted to apply only to retroactive impairments, that substantive value is a "reliance interest, an assurance that by entering into a contract one can render oneself immune from future shifts in the identity or thinking of one's elected representatives." Id. at 92. Ely assumes, however, that the remedy for a contract impairment is an injunction, not damages, as is clear from his remarks concerning the just compensation clause of the Fifth Amendment:

On first reading, the Fifth Amendment . . . may appear simply to mark the substantive value of private property for special protection from the political process . . . . [B] ut note that property is not shielded from condemnation by this provision. On the contrary, the amendment assumes that property will sometimes be taken and provides instead for compensation. Read through it thus emerges. . . as yet another protection of the few against the many, "a limit on government's power to isolate particular individuals for sacrifice to the general good." Its point is to "spread the cost of operating the governmental apparatus throughout the society rather than imposing it upon some small segment of it."

Id. at 97 (footnotes omitted). These arguments apply to this Note's interpretation of the contract clause, which requires just compensation to those affected by retroactive impairments. Such a contract clause is thus procedural.

37. This theory of the contract clause is procedural in two senses. First, it does not interpret the clause to protect a substantive value (e.g., freedom of contract). The Note's interpretation of the clause instead allows the states to choose among any number of substantive conceptions of contract law. Second, the theory is concerned with the process of legislative decisionmaking: Decisions to impair are upheld so long as they are made prospectively and generally.

38. While for convenience the Note speaks of the majority exploiting minorities, powerful and 
statutes than with prospective ones. Retroactive legislation enables decisionmakers to know which contracts an impairment will harm. In contrast, it is more difficult to predict which contracts will be affected by prospective legislation. ${ }^{39}$

In addition, the requirement of prospectivity inhibits majority tyranny by giving minorities notice that certain contracts are invalid. While a prospective change in contract law may eliminate a contractor's most profitable opportunity, it at least leaves that contractor free to make alternative exchanges. Retroactive impairments, however, operate on contracts made in reliance on existing law. Under current doctrine, the investments in those contracts are resources available for expropriation by politically powerful groups. ${ }^{40}$

The dangers posed by retroactive impairments can, however, be greatly reduced if the state compensates the victims of such impairments. ${ }^{41}$ The compensation requirement directly prevents majorities from imposing the costs of impairments on only a small section of the population. These costs must be borne instead by the general public as taxpayers. The impairment will thus be seen as a burden on everyone and will be made only if its overall benefits exceed its costs.

These provisions requiring generality and prospectivity serve the public interest in two ways. First, they encourage legislators to perform their function as it was traditionally conceived and to evaluate laws from the perspective of the common good. ${ }^{12}$ Because it is difficult to predict the harmful effects of a prospective change in contract law, more people will fear these effects than will actually be harmed by them. Similarly, more people will anticipate that a change in law might benefit them. This diffusion of benefits and costs discourages legislators from evaluating laws from an interest-group perspective. With the boundaries between groups blurred, a legislator will have a greater incentive to consider the populace as a single group and to rely on his genuine opinions about that group's

well organized special interests may exploit the majority as well. See M. OrSEN, THE LoGIC of Collective Action 63-65 (1965).

39. Cf. J. RAWLS, A ThEORY OF JUSTICE 136-42 (1971) (using ignorance in "original position" to ensure fairness of outcome to all).

40. For example, bondholders' investments might be expropriated by a change in the terms of the indenture. Cf. United States Trust Co. v. New Jersey, 431 U.S. 1 (1977) (legislation repealing bond covenant unconstitutional impairment).

41. If 42 U.S.C. $\S 1983$ (1976) applied to impairments of contracts, a damage remedy would already exist. Cf. Carey v. Piphus, 435 U.S. 247 (1978) (discussing "prerequisites for recovery of damages" by public school children deprived of due process). Section 1983, however, has been interpreted not to apply to rights asserted under the contract clause. See Poirier v. Hodges, 445 F. Supp. 838, 841-42 (M.D. Fla. 1978); Pudlik v. Public Serv. Co., 166 F. Supp. 921, 925 (D. Colo. 1958).

42. See J. ElY, supra note 14, at 78-88; F. HAYER, supra note 11, at 8-13, 20-21; G. WILLS, Explaining America: The Federalist 223 (1981) (discussing Madison's disapproval of representation of specific interests). 
interest. While policy disagreements will still exist, the nature of these disagreements between legislators will turn on different conceptions of the public interest. This is preferable to a situation in which disagreements turn instead on which interest groups will be affected. ${ }^{43}$

Second, the procedural approach promotes legislation that creates more benefits than costs. Majority rule will only produce such legislation if majorities are not allowed to create small benefits for themselves by imposing large costs upon minorities. ${ }^{44}$ By making it more difficult for majorities to identify and burden the victims of impairments, the requirements of prospectivity and generality tend to prevent such redistributions. ${ }^{45}$

\section{Policy Advantages of the Damage Remedy}

A damage remedy is superior to an injunction because damages provide the states with the flexibility to impair contracts retroactively when the benefits exceed the costs. So long as the victims of contract impairments are made whole through compensation, ${ }^{48}$ there is little reason to grant

43. The situation where a majority can exploit a minority may be described as a political externality: The majority does not bear the full costs of its behavior. $C f$. R. BORK, THE ANTITrust PARADOX 114 (1978) (defining economic externality as "[e]conomic activity [that] creates social costs ... not taken into account by the price system"). There is an interesting contrast between political and economic externalities. Economic externalities will not arise if the benefits and costs of an activity are fully concentrated in a decisionmaker. See C. Schultze, The Public Use of Private InterESTS 30-31 (1978). Political externalities, however, may be solved by diffusing the benefits and costs of collective action. In this way, no group is given opportunity to exploit another: Private benefits cannot be acquired without also producing public benefits and costs cannot be imposed only on some. This solution is required in the political sphere because there is no way of fully concentrating the benefits and costs of collective action on a particular group; and thus some mechanism for tying together the interests of different groups is necessary. In this respect, the diffusion of benefits and costs is an attempt to create an effect similar to what Rawls calls chain connection. See J. RAwLS, supra note 39 , at 80 . Nozick also suggests a way of tying together the interests of individual actors-the reciprocal ownership of shares in one another. R. Nozick, ANARCHy, State AND UTOPIA 180-90 (1974).

44. Cf. Ely, Constitutional Interpretivism: Its Allure and Impossibility, 53 IND. L.J. 399, 407 (1978) (discussing connection between democracy and utilitarianism); Bork, supra note 29, at 9-11 (discussing connection between democracy and "equal gratification principle").

45. The root idea has an analogy in welfare economics. Majority rule, limited by the contract clause as here interpreted, will produce only Kaldor-Hicks optimal changes. See generally Coleman, Efficiency, Exchange, and Auction: Philosophic Aspects of the Economic Approach to Law, 68 GalIF. L. REv. 221, 239-40 (1980) (defining Kaldor-Hicks efficient changes as those in which "the position of winners has been improved more than the position of losers has been worsened," as measured by consumers' willingness to pay). Majority rule unconstrained by the procedural approach to the contract clause, however, will often result in suboptimal changes under the Kaldor-Hicks standard. This does not make the procedural approach Kaldor-Hicks optimal in any technical sense. For example, the argument in the text ignores intensity of preferences, an issue that an efficiency claim should address. Nor does this imply that the public interest is merely a matter of efficiency.

46. The damage remedy for a breach of contract differs from the damage remedy for an impairment. In a breach, it is one of the parties who prevents the contract from being realized; in an impairment, it is the state, an external party, which interferes with the contract. As a result, the law of contract damages may not be very useful in developing the details of a damage remedy for impairment. A more appropriate analogy to contract impairment is the tort of interference with contract. This tort involves a third party's preventing two contractors from fulfilling their contract. See gener- 
those victims an injunctive remedy. ${ }^{17}$ In this respect, the damage remedy for impairments resembles the just compensation requirement for governmental takings of private property. ${ }^{48}$ Both requirements help to insure that property will be taken only when the taking is in the public interest. ${ }^{40}$ In addition, elementary fairness requires that if the public benefits from an impairment, the public, rather than the individual victims, should bear the costs of those benefits. ${ }^{.0}$

\section{The Reduction of Judicial Discretion Through the Procedural Approach}

The procedural approach would also eliminate much of the undesirable discretion that judges presently exercise under the contract clause balanc-

ally W. Prosser, HaNdBoor of THE LAW of TorTs $\S 129$, at 927-49 (1971) (discussing tort of interference with contract).

47. Cf. R. Posner, Economic Analysis of Law $\S \S 4.9$, 4.12, at 88-89, 95-96 (2d ed. 1977) (arguing that damage remedy for breach of contract serves efficiency). But of. Schwartz, The Case for Specific Performance, 89 YALE L.J. 271 (1979) (specific performance preferable to contract damages).

48. The just compensation clause provides that "private property [shall not] be taken for public use, without just compensation." U.S. CoNST. amend. V.

49. See L. TRIBE, supra note 14, $\$ 9-4$, at 463 (discussing compensation requirement as an attempt to limit arbitrary sacrifice of few to many); R. POSNER, supra note 47 , at $\S 3.5$, at 41 (compensation requirement limits takings to circumstances when property owner values property less than government). Because the contract clause does not prevent the states from exercising the power of eminent domain on contracts, see West River Bridge Co. v. Dix, 47 U.S. (6 How.) 507, 532-33 (1848); B. SchwARTZ, supra note 3, at 296, one might question the need for an independent damages remedy. A damages remedy is nonetheless necessary to serve the purposes that allow states to impair contracts in the first place. Eminent domain requires that the state initiate a proceeding in order to condemn property, see 6 P. Nichols, The Law of Eminent Domain $\S \S 24.11-.113$ (rev. 3d ed. 1983), while the damages remedy has the harmed contractors bring an action themselves. The damages remedy is superior in this respect since contractors know who has been impaired better than does the state. Eminent domain, moreover, requires that damage determinations occur before the statute works its impairments, id., while the damages remedy measures damages after the impairment. Again, the damages remedy is superior because the courts can estimate damages better after the impairment than before. The damages remedy is thus a more appropriate way of insuring that all victims of impairments are compensated but that the state pays for no more than the actual damages suffered. Moreover, statutes that impair retroactively are often needed immediately-or the state could have exempted prior contracts-but eminent domain proceedings may delay the operation of the statute.

50. See L. TRIBE, supra note 14, § 9-4, at 463; Michelman, Property, Utility and Fairness: Comments on the Ethical Foundations of "Just Compensation" Law, 80 HARv. L. REv. 1165, 1218-24 (1967). Another advantage of the damage remedy is that it provides the courts with the flexibility to focus on the real issue in a case while also preserving decisionmaking in accordance with rules. In Home Building \& Loan Ass'n v. Blaisdell, 290 U.S. 398 (1934), for example, a contract was impaired by a debt moratorium that permitted defaulting mortgagors to remain in their houses for a short period if they paid reasonable rental value. While this statute impaired the original mortgage contracts, the mortgagees thereby suffered little or no damage. Had the contract clause been interpreted to require only a damages remedy, the court could have held the statute to be an impairment, secure in the knowledge that the state could easily have paid for the minimal damages suffered. In the absence of a damages remedy, however, the Court was led to uphold the statute by in effect reinterpreting the contract clause to bar only unreasonable impairments. Id. at 444-47. This reasonableness test has since been used to permit much more significant impairments. See supra note 2. Thus, to avoid the rigidity of an injunction, the Court set a precedent that later courts have used to undermine contractual expectations and the Constitution. 
ing test. ${ }^{61}$ Because the procedural approach employs a clear rule, it circumvents the ad hoc decisionmaking characteristic of balancing. Courts using the procedural approach would not weigh the benefits of an impairment against its costs, but would merely determine if an impairment had occurred. $^{\mathbf{6 2}}$ Moreover, the procedural approach is framed in precise, nonpolitical terms. Balancing tests, on the other hand, require that judges orient their decisions around more political and philosophical concepts. ${ }^{\text {ss }}$ Such indeterminate concepts lead judges to consult their political prejudices. $^{\text {.4 }}$

The procedural approach would not, of course, result in errorless judicial interpretation. The compensation requirement means that the courts must calculate the damages caused by an impairment rather than just issuing an injunction. Nonetheless, calculating damages is an activity for which judges and juries have long been well-suited. Judges will also have

51. See supra 919-22.

52. In this respect, the difference between an absolute interpretation of the contract clause and the current balancing jurisprudence parallels the old controversy in antitrust law about whether or not judges should weigh the costs of a system of competition. In United States v. Addyston Pipe \& Steel Co., 85 F. 271, 284 (6th Cir. 1898), modified, 175 U.S. 211 (1899), Judge Taft rejected the view that the judge's role was to consider "how much restraint of competition is in the public interest, and how much was not" because such an inquiry would set the courts on "a sea of doubt." See generally $\mathbf{R}$. BORK, supra note 43, at 26-30 (discussing Addyston). In the jurisprudence of the contract clause, the balancing of individual and state rights has likewise set the courts on such a sea. The procedural approach would help to anchor them.

53. In assessing the harm caused to victims of impairments, for example, the Justices have supplemented the technical criterion of damages suffered with evaluations of meritorious behavior, see Allied Structural Steel v. Spannaus, 438 U.S. 231, 254 (1978) (impairment "will impose only minor economic burdens on employers whose pension plans are adequately funded") (emphasis added), and of reliance, see id. at 246 (impairment "severe ... in an area where reliance was vital") (emphasis added); see also supra note 10 (Justices' disagreements in Allied Structural Steel and United States Trust Co. result from differing evaluations of competing social ends).

54. A comparison of this Note's procedural approach with an application to the contract clause of Ely's participation-reinforcing theory of judicial review is instructive. See J. ELY, supra note 14. Although both approaches attempt to improve the processes of legislative decisionmaking, only the procedural approach defines a judicial role that acceptably limits discretion. Applying the participation-reinforcing theory to the contract clause requires courts to "scrutinize the manner in which the legislature has adopted the particular law, but not intrude upon the legislature's substantive policy judgment." Note, A Process-Oriented Approach to the Contract Clause, 89 YALE L.J. 1612, 1625 (1980). Such scrutiny would demand that the judiciary determine "whether the legislature made the judgments necessary to support the validity of the impairment," and "whether political processes functioned effectively to provide all interested parties with a fair opportunity to argue their cases or to challenge an adverse decision." Id. at 1645 . Judges would find this task much more difficult to perform than the relatively simple one required by this Note's procedural approach. The problem of distinguishing between a "fair" process that just happens to lead to unfortunate results and a malfunctioning process is characteristic of Ely's participation-reinforcing theory of judicial review. Under Ely's theory, judges would often evaluate the fairness of a legislative process in light of their view of the substantive outcumes that process produced. See Bork, The Impossibilty of Finding Welfare Rights in the Constitution, 1979 Wash. U.L.Q. 695, 700; Cox, Book Review, 94 Harv. L. Rev. 700, 710-11 (1981); Tushnet, Darkness on the Edge of Town: The Contributions of John Hart Ely to Constitutional Theory, 89 YALE L.J. 1037, 1053-56 (1980). The procedural approach, by limiting discretion, would avoid this admixture of substance and procedure, but still promote fair legislative decisionmaking. 
to exercise some discretion in defining which agreements fall within the scope of the contract clause. ${ }^{55}$ But this exercise of discretion is acceptable, for judges are choosing a rule to limit their future discretion rather than making an ad hoc decision. ${ }^{\text {se }}$

\section{B. Constitutional Arguments for the Procedural Approach}

The procedural approach to the contract clause is correct as a matter of constitutional law. This is true whether one considers the Framers' intent, the constitutional text, or analogies to other constitutional provisions.

\section{The Intent of the Framers}

The procedural approach accords with the Framers' view of the contract clause as a device to improve legislative decisionmaking. ${ }^{57}$ The Framers adopted the clause in response to the state debtor relief statutes passed in the $1780^{\prime} \mathrm{s}^{58}$ by debtors who formed a large part of the population. The statutes allowed debtors to reduce their loan obligations in a variety of ways. ${ }^{\text {so }}$

Debtor relief statutes were a paradigmatic example of what the Framers disliked about the state republics. These statutes were able to pass because the revolutionaries of 1776 , believing that small republics would insure a homogeneity of interests among the people, had not imposed strict limitations upon the state legislatures. ${ }^{60}$

55. For example, judges must decide whether a marriage contract or a corporate charter is a contract within the meaning of the contract clause. See infra pp. 936-38 (discussing corporate charters); note 97 (discussing marriage contracts).

56. See supra p. 922.

57. In Federalist No. 44, Madison discusses the contract clause with the process-oriented clauses prohibiting bills of attainder and ex post facto laws. THE FEDERALIST No. 44, at 282-83 (J. Madison) (Rossiter ed. 1961). In arguing for the three clauses, Madison does not distinguish among them; he considers reasons for adopting one to be reasons for adopting all. The connection among these clauses is further suggested by the fact that the Framers grouped them together in Article $I, \S 10$ of the Constitution. See also infra note 59 (clauses protecting creditors from state inflation of currency also placed in Art. I, $\S 10$ ). The Framers' process-oriented intent is also shown by the fact that the contract clause was applied only to the states. If the Framers were simply concerned to protect freedom of contract, they should have applied the clause to the Federal Government as well. Federalist No. 10 suggests that they restricted the clause because they had faith in the process of legislative decisionmaking in large republics.

58. See Home Bldg. \& Loan Ass'n v. Blaisdell, 290 U.S. 398, 454-61 (1934), and sources cited therein (contract clause inserted in response to state debtor relief); C. BEARD, AN ECONOMIC INTERPRETATION OF THE Constitution OF THE UNITEd States 28 (1929) (small farmers and poor urban dwellers made up "a large debtor class").

59. "State laws were passed suspending the collection of debts . . ., providing for the emission of paper money, delaying legal proceedings, etc." Home Bldg. \& Loan Ass'n v. Blaisdell, 290 U.S. 398, 454 (1934) (Sutherland, J., dissenting). The Framers sought to protect creditors from state inflation of the currency through a number of provisions preceding the contract clause in Article I, $\$ 10$ : "No State shall . . . coin Money; emit Bills of Credit; make any Thing but gold and silver Coin a tender in Payment of Debts." U.S. CoNST. art I, § 10, cls. 3-5.

60. See G. WoOd, Creation of THE American Republic 1776-1787, at 57-58 (1969) (revo- 
The Federalists rejected this belief in homogeneous interests. The Framers saw the clash between creditors and debtors as strong evidence of the danger of expropriation by a majority and sought to protect against such expropriation by limiting the state legislatures. ${ }^{61}$ Believing that government should promote the general welfare, rather than the welfare of a particular group, ${ }^{62}$ the Framers included the contract clause to prevent the majority of debtors from abusing the creditor minority. ${ }^{63}$ The contract clause was thus an attempt to insure that state legislation would benefit all the people. ${ }^{64}$

\section{Analogy to Other Requirements of Prospectivity and Generality in the Constitution}

Although the contract clause has long been analogized to the balancing doctrine of substantive due process, ${ }^{65}$ the clause should instead be viewed as one of the many provisions in the Constitution that impose requirements of prospectivity and generality upon government. ${ }^{66}$ The contract clause permits the states to regulate contracts so long as they meet requirements of prospectivity and generality. ${ }^{67}$ The Framers placed great trust in these requirements, ${ }^{68}$ as is evidenced by the many provisions requiring prospectivity and generality that can be found throughout the Constitution. Such requirements include the bar on federal and state bills

lutionaries believed that small state republics would promote homogeneous populations and temper factionalism).

61. The Federalist No. 10 (J. Madison); see B. Wright, supra note 3, at 4 ("one of the principal causes for dissatisfacion with the prevailing state of affairs under the Confederation among the well-to-do classes was the mass of state legislation which was highly unwelcome to creditors as it was popular with debtors").

62. See J. Ely, supra note 14, at 79 (Framers envisioned republic "in which the representatives would govern in the interests of the whole people").

63. See Blaisdell, 290 U.S. at 455-64, and sources cited therein; L. TRIBE, supra note 14, § 9.5, at 466 (contract clause "included primarily to protect private contracts from improvident majoritarian impairment").

64. Cf. J. ELY, supra note 14, at 80-100 (many constitutional clauses were attempts to insure representation of all people).

65. See supra pp. 924-25.

66. The concept of generality (or equality) is often criticized as being vacuous. E.g., Sandalow, Racial Preferences in Higher Education: Political Responsibility and the Judicial Role, $42 \mathrm{U}$. CHI. L. REv. 653, 655 (1975); Westen, The Empty Idea of Equality, 95 Harv. L. Rev. 537 (1982). This criticism of generality is important. Almost all laws are general with respect to some criteria; the question is what are the relevant criteria. The procedural approach, however, is not plagued by the vacuity problem. Since the contract clause does not directly mention generality or equality-in contrast to the equal protection clause, for example-it is not necessary to decide what criteria to generalize. Rather, by simply applying the clause, it will produce more generalized decisionmaking.

67. See supra pp. 925-28.

68. Madison once observed that "the House of Representatives [is restrained] . . . from oppressive measures [because] . . . they can make no law which will not have its full operation on themselves and their friends, as well as on the great mass of society." THE FEDERALIST No. 57, at 352 (J. Madison) (C. Rossiter ed. 1961). 
of attainder ${ }^{80}$ and ex post facto laws; $;^{70}$ the requirement of uniformity in federal bankruptcy and naturalization law; ${ }^{71}$ the requirement that "[a]ll duties, imposts and excises shall be uniform throughout the United States",;2 the equal protection clause; ${ }^{73}$ the prohibition on the taking of private property without just compensation; ${ }^{74}$ and the prohibition on cruel and unusual punishment. ${ }^{75}$

\section{Constitutional Arguments for the Damage Remedy}

Some might argue that the damage remedy proposed by this Note is inconsistent with the constitutional text: The contract clause prohibits all impairments, not just impairments without compensation. This objection fails for at least two reasons.

First, the procedural approach does prohibit all impairments and thus is in accord with the constitutional text. The approach merely changes the remedy for impairments from an injunction to damages. Since the Constitution does not specify a remedy, any remedy that protects contractors' rights should be permissible; ${ }^{78}$ providing full compensation for damages incurred clearly protects those rights.

Second, it has long been recognized that vested contract rights, as a form of property, are subject to the state's power of eminent domain. ${ }^{77}$

69. U.S. ConST. art. I, § 9, cl. 3.

70. U.S. CoNST. art. I, $\S 10$, cl. 6.

71. Congress can only "establish an uniform Rule of Naturalization, and uniform Laws on the subject of Bankruptcies throughout the United States." U.S. CoNST. art. I, § 8. See Railway Labor Executives Ass'n v. Gibbons, 455 U.S. 457, 472 n.14 (1982) (Rock Island Transition and Employee Assistance Act, which applies to only one railroad, violates uniformity; 'Framers' intent to achieve uniformity among the Nation's bankruptcy laws is also reflected in the Contract Clause. Apart from and independently of the Supremacy Clause, the Contract Clause prohibits the States from enacting debtor relief laws which discharge the debtor from his obligations... unless the law operates prospectively.") (citations omitted); cf. 3 AM. JUR. 2d Aliens and Citizens $\$ 132$, at 1006 (1962) ("Congress may grant or withold the privilege of naturalization on any grounds, or without any reason, as it sees fit, the only limitation being the constitutional one of uniformity. This requirement is construed to mean only that the mode or manner of naturalization prescribed must have uniform operation in all the states.") (citation omitted). Consequently, citizenship can be conferred by special act. See Congressional Research Service, The Constitution of the United States of america: Analysis ANd Interpretation, S. Doc. No. 82, 92d Cong., 2d. Sess. 284 (1972).

72. U.S. CoNST. art. I, § 8.

73. U.S. CoNST. amend. XIV, § 1, provides that no state shall "deny to any person within its jurisdiction the equal protection of the laws."

74. U.S. CoNST. amend. V provides that "private property [shall not] be taken for public use, without just compensation."

75. U.S. CoNST. amend. VIII.

76. The distinction between right and remedy is implied by the text of the contract clause itself: The clause does not prohibit simply impairments, but rather impairments of the obligation of contracts. The clause's focus on the obligation of contracts was once used to permit changes of remedies that did not affect contractors' rights. See United States Trust Co. v. New Jersey, 431 U.S. 1, 20 n.17 (1977) (courts no longer rely on remedy/obligation distinction since obligations can now be modified without necessarily violating the contract clause); Sturges v. Crowninshield, 17 U.S. (4 Wheat.) 122, 200-01 (1819).

77. See El Paso v. Simmons, 379 U.S. 497, 517 (1965) (Black, J., dissenting); West River Bridge Co. v. Dix, 47 U.S. (6 How.) 507, 532-33 (1848). 
The damages remedy for contract impairments differs from the exercise of eminent domain only by making the process of government compensation operate more smoothly. ${ }^{78}$ The damages remedy is thus consistent with the fullest protection of contract rights given their status as property. ${ }^{79}$

\section{The Contract Clause, Corporate Charters, and GoRPORATE LAW}

The procedural approach to the contract clause treats prospective and retroactive impairments differently. Retroactive impairments must be accompanied by compensation, while prospective impairments do not require compensation. This distinction between prospective and retroactive action has implications for corporate law. ${ }^{80}$

Since Dartmouth College v. Woodward ${ }^{81}$ corporate charters have been contracts under the contract clause. ${ }^{\mathbf{8 2}}$ Dartmouth College suggested that all regulations of corporations would be contract impairments. This result

78. See supra note 49.

79. The procedural approach to the contract clause provides the states with the option of retroactively impairing so long as just compensation is paid. Where compensation was owed, it would have to be sought by the impairment victim in a suit against the state for damages. This appears to raise a problem, however, since the Eleventh Amendment and the doctrine of sovereign immunity would bar many damage actions from being brought in federal or state court. See Edelman v. Jordan, 415 U.S. 651 (1974); Ex parte Young, 209 U.S. 123 (1908). See generally C. WRIGHT, LAW OF FEdERAL CourTs 286-92 (4th ed. 1982) (discussing doctrine of Ex parle Young).

The solution to this problem derives from the obligation of the courts to protect contract clause rights. If the option of paying compensation were provided to states that were also insulated by sovereign immunity, the contract clause would become a nullity and courts would be shirking their duty to enforce the Constitution. Thus, the Constitution requires that the courts provide the option of paying just compensation only to states which have also waived their sovereign immunity.

The states thus have a choice when they are deciding whether to impair. In passing a statute that might affect existing contracts, a state must decide whether to apply the statute prospectively, thereby exempting existing contracts, or to apply the statute retroactively, thereby waiving its sovereign immunity and incurring the need to compensate. In making this decision, the state will weigh the benefits of having the statute applied immediately against the costs of paying damages. Without a damage remedy, however, the states would not have this choice-they would be forced to exempt existing contracts (or to exercise their power of eminent domain). Because the damages remedy provides the states with the additional option of waiving their sovereign immunity and paying damages, the damages remedy leaves the states better off than if retroactive impairments could be enjoined.

80. The procedural approach also has implications for public contracts. In United States Trust Co. v. New Jersey, 431 U.S. 1, 26 (1977), the Supreme Court held that the impairment of a public contract is subject to stricter scrutiny than a private contract because a state's self-interest is at stake when it considers whether to impair a public contract. This Note rejects such an approach. If an influential corporation persuades the legislature to adjust its contract, this impairment is at least as suspicious as one made directly for the benefit of the state government. Instead, the procedural approach prohibits all retroactive impairments because the legislature can predict which minority will bear the burden of an impairment. Whether the beneficiary is the state itself or one of its favored private interests is unimportant.

81. 17 U.S. (4 Wheat.) 518 (1819).

82. Id. at 643-50; State ex rel. Starkey v. Alaska Airlines, 68 Wash. 2d. 318, 323, 413 P.2d 352, 358 (1966); W. Cary \& M. Eisenderg, Cases and Materials on Corporations 1615-19 (5th ed. 1980); H. Henn \& J. Alexander, Law of Corporations 951-53 (3d ed. 1983). 
was avoided, however, when the states followed Justice Story's concurrence and reserved the power, in corporate charters, to modify those charters subsequently. ${ }^{\mathbf{8 3}}$ Since later charters provided for modifications by the state, the Court found no impairment. ${ }^{84}$

While Dartmouth College may in theory still be good law, reservations of power by the states have overruled it as a practical matter. ${ }^{85}$ The contract clause no longer acts as a bar to state regulation of corporate charters.

The procedural approach, however, rejects the principle that states can reserve the power to regulate contracts. If the states can reserve the right to modify contracts, the values protected by the contract clause are undermined. ${ }^{88}$ Once the states have reserved the right to modify existing contracts, they are able to take retroactive and particular action. ${ }^{87}$ Although the procedural approach forbids reservations, it nonetheless allows states to regulate corporations, since the relevant agreements involving the state, corporations, and shareholders are outside the scope of the contract clause.

There are three agreements recognized in a corporate charter: one between the state and the corporation, another between the corporation and the shareholders, and a third among the shareholders. ${ }^{88}$ The first agreement is public, while the second and third are private. Under the procedural approach, none of these agreements insulates corporations from changes in state corporation law.

\section{A. Corporate Charters}

While Dartmouth College involved a special charter between the corporation and the state, corporations are no longer formed by charters ${ }^{80}$ but

83. 17 U.S. at 712 .

84. See Miller v. State, 82 U.S. (15 Wall.) 478 (1872) (modification of charter upheld as part of reserved power); B. SchWARTZ, supra note 3 , at 303.

85. See H. HenN \& J. AlEXANDER, supra note 82, at 978; B. SChwARTz, supra note 3, at 304 ("The result [of the reserve power] is that the practical impact of Dartmouth College has been all but climinated ....").

86. In this respect, the reservation doctrine resembles an unconstitutional condition: It attempts to achieve indirectly what cannot be achieved directly. See generally Van Alstyne, The Demise of the Right-Privilege Distinction in Constitutional Law, 81 HARv. L. REv. 1439, 1445-59 (1968) (state cannot remove privilege because of citizens' exercise of rights).

87. See supra pp. 926-27.

88. H. HENN \& J. ALEXANDER, supra note 82, at 951-55; Note, Limitations on Alteration of Shareholders' Rights by Charter Amendment, 69 HARv. L. REv. 538, 540 (1956). The charter impaired in Dartmouth College is an example of the public corporate contract. The state impaired this contract by passing legislation that, inter alia, ousted control from the existing trustees. Id. at 625 . Western Foundary Co. v. Wicker, 403 Ill. 260, 85 N.E.2d 722 (1949), involved two private corporate contracts. An amendment voted by $97 \%$ of the preferred shareholders cancelling unpaid accumulated preferred dividends was held to "affect," but not impair, the contracts among the shareholders and those between the corporation and the shareholders.

89. R. Winter, Government and the Corporation 1-3 (1978). 
rather are created pursuant to state enabling acts. ${ }^{80}$ Special corporate charters possessed the characteristics of contract: They involved a specific agreement between the state and a particular entity, the future corporation. Enabling acts, in contrast, are general statutes permitting all who meet certain conditions to operate in the corporate form. ${ }^{91}$ To view enabling acts as contracts therefore requires a strained analysis. Since enabling acts only create the opportunity for organizing in a certain form, they are more naturally viewed as regulations of business. ${ }^{92}$ If enabling acts are held to be "contracts," then consistency would require finding "contracts" throughout much of the regulated economy. ${ }^{\text {93 }}$

No contract, therefore, should be held to exist between the state and corporations formed pursuant to enabling acts. With respect to such corporations, the Supreme Court should recognize the reality of the past one hundred and fifty years and overrule the doctrine of Dartmouth College. ${ }^{94}$ Because of the current ability of states to reserve the right to modify charters, this overruling would not upset current expectations.

\section{B. Contracts Involving the Shareholders}

Courts should also consider the two private contracts-that between the corporation and the shareholders, and that among the shareholders-to be beyond the scope of the contract clause. In the typical case, the contract clause does not unduly limit the ability of the state to regulate contract law. Because contracts are not usually of very long duration, the state's ability to regulate prospectively is effective. Gorporations, however, can exist in perpetuity, so there is no opportunity for the states to regulate existing corporate contracts prospectively. Thus, private corporate contracts limit the power of the state much more than the usual, private contract.

Moreover, if private corporate contracts were protected by the contract clause, the states would have to adopt a prospective regulation limiting the existence of new corporations to a finite period or leave new corporations insulated from uncompensated changes in corporation law. But limiting the lifespan of new corporations would undermine one of the purposes of

90 See, e.g., N.Y. Bus. CoRp. LAw $\S \S 401-04$ (McKinney 1982); Ill. ANN. Stat. ch. 32, § 157.46-.51 (Smith-Hurd 1982).

91. Indeed, the general character of enabling acts has been considered so important that most state constitutions forbid the creation of corporations by special acts of the legislature. Note, supra note 88, at $540 \mathrm{n} .20$ and constitutional provisions cited therein.

92. Dodd, Dissenting Stockholders and Amendments to Corporate Charters, 75 U. PA. L. REv. 585, 594-95 (1927).

93. The licensing of an attorney, for example, would be a contract. The contract clause might then prevent the state from later changing the bar's obligations.

94. As long as this overruling is done openly and for all corporate charters, it is consistent with standards of judicial interpretation presented earlier. See supra pp. 919-22. 


\section{Contracts Clause}

the corporate form-perpetual life. ${ }^{95}$ By interpreting the contract clause so that the states are forced to eliminate perpetual life, courts would probably be harming corporate contractors. ${ }^{96}$ Both the state and corporate contractors would be better off if corporate contracts were held to be outside the scope of the contract clause. ${ }^{97}$

This argument is bolstered by the existence of competition among the states. Because incorporations increase state tax revenues and capital is mobile, states compete to charter corporations by passing laws that attempt to maximize shareholder returns. ${ }^{98}$ This competition furthers the values of legislative process that underlie the procedural approach by giving the states an incentive to protect shareholders. This competition would be stifled if the contract clause were held to insulate corporate contracts from statutory alteration.

-Michael B. Rappaport

95. W. Cary \& M. Eisenberg, supra note 82, at 21-22.

96. We can be reasonably confident that corporate shareholders benefit more from perpetual life than they are harmed by having their charters subject to state regulation, since they could have eliminated both by conducting business as a non-corporate entity. Of course, there are other benefits to the corporate form besides perpetual life. See W. CARY \& M. EIsEnBERG, supra note 82, at 21-22. The benefits to being protected by the contract clause, however, are greatly reduced, if not made negative, by the existence of competition among the states for incorporations. See infra pp. 936-37.

97. These points concerning perpetual life can be subsumed under a more general principle. Modern theories of contract have distinguished two types of contract-classical and relational contracts. Williamson, Transaction Cost Economics: The Governance of Contractual Relations, 22 J.L. \& EcoN. 223, 236-38 (1980). Classical contracts-the more traditional kind-are of short duration, and have the terms of the contract largely specified in the document. Relational contracts, on the other hand, are of longer duration with vague terms to be given content as circumstances unfold. The contract clause makes much more sense when applied to classical contracts than to relational ones. As mentioned above, contracts of short duration do not greatly restrict the power of the state to regulate. Classical contracts also involve much more reliance on the specific terms of the document, which an impairment would tend to upset. The jurisprudence of the contract clause implicitly recognizes the relative inappropriateness of the clause to non-classical contracts by holding marriage contracts beyond the scope of the contract clause. See Maynard v. Hill, 125 U.S. 190 (1888); Flora v. Flora, 166 Ind. App. 620, 337 N.E.2d 846, 851 (1975). The courts should extend this recognition to corporate contracts.

98. R. WINTER, supra note 89 , at 7-16. 